IRA-International Journal of Management \& Social Sciences

ISSN 2455-2267; Vol.09, Issue 01 (October 2017)

Pg. no. 38-46

Institute of Research Advances

http://research-advances.org/index.php/RAJMSS

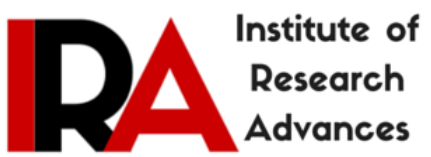

\title{
Indian Newspapers Framing of ISIS Coverage: A Content Analysis
}

\author{
Dr. J. Madhu Babu ${ }^{1} \&$ S.Venkateswarlu ${ }^{2}$ \\ ${ }^{1}$ Assistant Professor, Department of Journalism and Mass Communication, Acharya Nagarjuna \\ Univeristy, Guntur, Andhra Pradesh, India. \\ ${ }^{2}$ Research Scholar, Department of Journalism and Mass Communication, Acharya Nagarjuna \\ University, Guntur, Andhra Pradesh, India.
}

Type of Review: Peer Reviewed.

DOI: http://dx.doi.org/10.21013/jmss.v9.v1.p5

\section{How to cite this paper:}

Babu, J.M., Venkateswarlu, S. (2017). Indian Newspapers Framing of ISIS Coverage: A Content Analysis. IRA-International Journal of Management \& Social Sciences (ISSN 2455-2267), 9(1), 38-46. doi:http://dx.doi.org/10.21013/jmss.v9.n1.p5

(C) Institute of Research Advances.

\section{(cc) $\mathrm{EY}$-NC}

This work is licensed under a Creative Commons Attribution-Non Commercial 4.0 International License subject to proper citation to the publication source of the work.

Disclaimer: The scholarly papers as reviewed and published by the Institute of Research Advances (IRA) are the views and opinions of their respective authors and are not the views or opinions of the IRA. The IRA disclaims of any harm or loss caused due to the published content to any party.

Institute of Research Advances is an institutional publisher member of Publishers Inter Linking Association Inc. (PILA-CrossRef), USA. The institute is an institutional signatory to the Budapest Open Access Initiative, Hungary advocating the open access of scientific and scholarly knowledge. The Institute is a registered content provider under Open Access Initiative Protocol for Metadata Harvesting (OAI-PMH).

The journal is indexed \& included in WorldCat Discovery Service (USA), CrossRef Metadata Search (USA), WorldCat (USA), OCLC (USA), Open J-Gate (India), EZB (Germany) Scilit (Switzerland), Airiti (China), Bielefeld Academic Search Engine (BASE) of Bielefeld University, Germany, PKP Index of Simon Fraser University, Canada. 


\begin{abstract}
A 22-year-old youth, a native of Andhra Pradesh, who had converted to Islam and allegedly joined the Islamic State terror group taking an oath to carry out subversive activities in the country at the instigation of a Mumbai-based IS sympathiser, was arrested by the Hyderabad police on July 24, 2017.This stunning incident shocked the public and police officials. It shows that ISIS impact on Indian youth. This incident inspired the researchers to do research on coverage of ISIS by Indian Newspapers. The rise of ISIS in 2014, in this reason the researchers selected the August $1^{\text {st }}$ to December 31, in 2014 (5 months' time period) for the content analysis. In this research the researchers selected four Indian newspapers two from English (The Hindu and The Times of India) two from Telugu (Andrajyothi and Prajasakthi).It is not a random sample, it is a purposive sample. The coverage shows the intensity of ISIS activities. This study focused on investigating frames employed when covering ISIS and terrorismrelated events in Indian newspapers. All data collected were analysed using simple descriptive statistics. Statistical techniques as chi-square and co-efficient of imbalance have been used for analysis.
\end{abstract}

Keywords: ISIS, Newspapers, News frames.

\title{
Introduction
}

At the end of the $20^{\text {th }}$ century world community had faced sudden increase and terrorist activity and now it becomes more serious every day and has more cruel forms. This mass media and it has role in coverage of terrorism and has the mechanism of their interaction between them. On the one hand, they need mass media to spread their ideas. On the other hand, mass media also use terrorism coverage to broaden its audience. Both feed and use each other while implementing their own interest viz-a-viz Terrorist- political, Mass mediacommercial.

Former Prime- Minister of Great Britain Margaret Thatcher is famous by her statement about mass media "Oxygen providers without which terrorists would not survive (Holmes, D., 2007).

Mass media cover mainly the most impressive terrorist attacks taking place is the countries which are important strategy of objects by some reasons or play important in world affairs and when Terrorist Attacks influences global economy. Examples can we found in Conflicts in Africa, Laos, Cambodia-These do not attract attention of mass media and do not disturb world community while events in Parisian gulf are considered as direct threat for the whole world. As a result different interpretations of terrorism by different national governments lead to double standard policies, formation by means of mass media of images of good and bad, Dangerous and useful terrorist which allow to 'legitimize' their actions at the territory of some countries.

\section{ISIS Origin}

The rise of ISIS in 2014 and its claim of the establishment of the Islamic State have introduced a threat of unprecedented magnitude to the international community. ISIS has presented a new version of extremism and terrorism to the world. Despite counter-offensives like aerial bombings and ground combat on multiple fronts, ISIS continues to survive and has been able to demonstrate its robust and lethal capabilities with attacks in many countries and to spread its influence worldwide. The post Arab Spring chaos in many Middle Eastern countries specifically in Iraq's neighbourhood allowed to group to capture territory and establish its rule projecting it as the Islamic State - the Caliphate. As Al Qaeda's leadership of the jihadist movement began to wane especially after the killing of Osama bin Laden, many groups and individuals that Al Qaeda mentored with ideology, training and financing are now increasingly turning to ISIS and Abu Bakar al Baghdadi for strategic leadership and inspiration.

\section{ISIS and Media}

More recently the ISIS has started publishing several magazines and news sheets to propagate its campaign among the locals, while anyone following the groups' activities can also get access to them on internet. The jihadist group has also launched an online magazine to influence its supporters and recruit more fighters. The ISIS magazine named "The Islamic State Report" projects the life within the so-called Islamic state and propagates the benefits of living under the caliphate. ISIS often publishes photographs and interviews of its fighters as well as citizens showing how they are enjoying prosperity under the shade of the Caliphate. The ISIS magazines also publish interviews and pictures of captured soldiers and spies to warn foreign and local opponents and scare their rivals, who are trying to infiltrate the organization. 
ISIS media wing use Twitter, YouTube, Facebook, Instagram, Tumblr and other social networking websites to upload its propaganda material and observe dispersal of its ideas globally in matter of minutes or hours. At that stage, ISIS's main focus was to gain popularity in Iraq and Syria and strengthen its position in Arab world.

As ISIS's crimes started to receive extensive media coverage, masked men holding knives, guns and black flags became a fixture of broadcast news. Every new story of ISIS fighters beheading hostages or brutally killing civilian population becomes a challenge for media to tell the truth without either propagating or censoring its evil. Several media channels often unintentionally fall into the ISIS trap and propagate their radical ideas and/or induce fear among the citizens. While it is also observed that some teenagers do get inspired by the terrorist group and attempt to imitate their brutal acts. The ISIS has also employed highly skilled social media experts in its electronic warfare and propaganda campaign, who are not only active in Syria and Iraq but also maintain contacts and links within several other countries and regions including UK, U.S. Australia, South Asia, Middle East and North Africa(Ahsan 2015).

\section{ISIS's Strategy}

Today, ISIS has become a transnational phenomenon with an estimated 80,000 fighters including 30,000 Iraqis and Syrians and 20,000 foreigners combating in Iraq and Syria and hundreds of thousands of supporters worldwide. According to Western security and intelligence estimates ISIS fighters in Syria and Iraq grew from 30,000 in 2014 to 50,000 in 2015 and likely to increase further in coming months as the group grabs more tertiary. (RohanGunaratna2016)

\section{Framing Theory}

The introduction of the framing approach is often credited to Goffman and Bateson as noted by Reese (2001). Goffman in (1974) defines frames as "the principles of organization which govern events... and our subjective involvement in them" (p. 192). Further, Tuchman explains that frames "turn non recognizable happenings or amorphous talk into a discernible event" (1978, p. 192). Also, De Vreese (2005) defines a frame as "and emphasis in salience of different aspects of a topic" (p. 53).McQuail, in his book "Theories of Mass Communication" (2009), framing research via two main approaches: the first is about how the news is formed by journalists and the second is about how the public is affected by framing (p.557). He also describes framing as a "way of giving some overall interpretation to isolated items of fact" (p. 380).

According to Semetko and Valkenburg (2000), the most common generic frames inthe news is: conflict, human interest, economic consequences, morality, and responsibility. Semetko \&Valkenburg (2000) content analyzed over 3000 news stories in1997 in four newspapers and three daily television news programs. The study tested thevariance in the use of frames among outlets and topics. They investigated five news frames, namely attribution of responsibility, conflict, human interest, economic consequences, andmorality, and found that the responsibility and the conflict were the most used frames inthe news. Also, they claim that television news in Holland was predominantly episodic.However, regarding the Dutch press, they state "the reverse was true: $32 \%$ of stories wereepisodic and 68\% were thematic" (p. 93-102).

Dimitrova, Kaid, Williams, \& Trammell (2005) used a similar framework and studied quantitatively the immediate coverage of the 2003 Iraq War in international news web sites. The sample contained of 246 news websites from 48 countries. These websites consisted of newspapers, TV channels, and radio stations, one of which was CNN. The study found variation in "the sources, issues, and amount of initial coverage on each web site" (p.31). They used six frames in their study as follows: conflict, human interest, diagnostic, responsibility, media self-referential, and prognostic.

Iyengar (1991) distinguishes between episodic and thematicframing, where the episodic framing is more eventoriented and fragmented, whilethematic framing puts the event in context (p. 14).

\section{Framing Terrorism:}

Study of how terrorist acts are framed attempt to bring together by examining both how acts are covered and the impact of this coverage on the public. Especially Nacos et.al (2003) proposed a model of framing process for terrorist events that is located in social cultures out of which government terrorist, and group frames emerges and interact to develop into the new frames, which directly inform public opinion and - connects to the policy agenda.

Nacos and Torres Reyna (2003) investigated how MuslimAmericans were portrayed in the U.S Newspapers to find that when describingMuslimAmericans newspapers mostly employed episodic frames over thematic once. 
Framing is on theoretical concept that many political and mass communication scholars have repeatedly applied to study of media coverage of terrorism.(Barnett and Reynolds 2009:47), because framing one of the most relevant approaches to explaining how the media influence audiences attitudes through words, wars and conflict(Fahmy and Al-Himat 2011,218). Tan et.al (1991, argued that, the concept of media framing is important because it offers an alternative to old.' Objectivity and Bias" Paradigm, it helps us understand mass communication effects; it offers valuable suggestions for communication practitioners" (pp94-94). Neuman (et.al 1992) identified 'human impact', 'powerlessness', 'economics', 'moral values', 'conflict', as the most common generic frames used by both media and audience ( $\mathrm{pp} 75$-75)

\section{Review of Literature}

Gans (1979) observes that American news media "often limit themselves only to themost dramatic overseas events." Norris, Kern and Just (2003) define terrorism as theorganized use of forced intimidation against civilians in order to achieve political goals, while framing is the "selection to prioritize some facts, images, or developments overothers, thereby unconsciously promoting one particular interpretation of events" (pp. 6,11).

Jasperson and El-Kikhia (2003) compared CNN and Al-Jazeera via analyzing 164 news stories. After studying three types of frames: governance, military, and humanitarian, they found important differences between CNN and Al-Jazeera in their assessment andexplanation of the war. In terms of the military frame, they found that AlJazzera's coverage did not focus on the military and strategic issues as much as CNN (p. 126).

Aday, Livingston, and Hebert (2005) studied the Iraq War coverage among six TVNetworks (five in the U.S. plus Al-Jazeera) in order to assess the fairness and balance of the news. One of the findings was that the U.S. networks mostly ignored any "antiwarsentiment" while Al-Jazeera "devoted more coverage to protests and diplomacy," Also; the study shows thatepisodic coverage was dominant across all the networks (p.17-18).

Papacharissi\& Oliveira (2008) conducted a comparative framing study of media coverage of terrorism events in the United States, the United Kingdom, and Spain. Prominent newspapers in the United States and the United Kingdom were analyzed viaQuantitative and qualitative methods. They found that U.S. newspapers tended to useepisodic frames while the U.K. ones relied on thematic coverage (p. 70).

Studies focusing on news coverage of terrorism included content analyses on U.S. embassy bombings in Kenya and Tanzania in 1998, and the September 11 attacks in 2001incidents. In this study, Schaefer (2003) compared the coverage of U.S. and African newspapers. He analyzed their content quantitatively and qualitatively and found that "geographic proximity and the local angle influenced the prominence and amount of coverage" of the events under study (p. 93).

\section{ISIS Roots in Andhra Pradesh}

A 22-year-old youth, a native of Andhra Pradesh, who had converted to Islam and allegedly joined the Islamic State terror group. This is probably the first arrest of a person hailing from AP who joined the radical terror organisation. The arrest comes months after the National Investigation Agency (NIA) traced ISIS links to AP. Konakalla Subramanyam alias Omer was a native of Challapally mandal in Krishna district of Andhra Pradesh. After converting to Islam he has been staying in Hyderabad.

The police said Subramanyam had embraced Islam in 2014. Later, he visited Gujarat and received training in religious rituals and scriptures. He also visited Srinagar and some other places in Tamil Nadu and Mumbai. He embraced Islam, and he changed his name to Omer. He joined a team of preachers and went to Gujarat to participate in a religious event. Then he joined a madrasa where he learned Urdu. "In Hyderabad, his access to social media like Facebook, WhatsApp increased; he got in touch with one Abu Qahafa AlHindi of Mumbai, an ISIS sympathiser. Through Facebook, Omer moved to his place in the guise of a caretaker.

\section{Need of the Study}

Above stunning Incident shocked the public and police officials. It shows that ISIS Impact on Indian Youth. This Incident inspired the researchers to do research on coverage of ISIS by Indian Newspapers. The coverage shows the intensity of ISIS activities. This study focused on investigating frames employed when covering ISIS and terrorism-related events in Indian newspapers. 


\section{Research Questions}

RQ1 Did the Indian press give top priority to ISIS activities in the reporting?

RQ2 Are there any variations in slants and frames of ISIS news in in Selected Dailies?

RQ3 Are there any variations in Newspaper location Analysis of the ISIS News Items in Selected Dailies?

RQ4 How did the direction of treatment given by two newspapers coverage differs?

\section{Research Methodology}

Researcher has adopted content analysis method for this study. Content analysis is essential to finding patterns, based on which scholars and researchers can methodically evaluate news media and its use of framing. In term, this allows for the comparison of possible agenda setters' bias of the event (Riffe, Lacy \& Fico,2005,p.3).

\section{The Sample Frame Work}

A purposive sample consisting of four leading daily newspapers (two from EnglishThe Hindu, The Times of India and two from Telugu dailies Andhra jyothi, Prajasakti were taken. The English newspapers were takenthe prime consideration their circulation. But the Telugu newspapers were takenaccording to the coverage.Other two prominent newspapers Eenadu and Sakshi were not concentrate in this issue.Inthis reason the researcher selected above two Telugu newspapers.

\section{Sampling Procedure}

The universe for the study comprises all the editions of the four selected dailies published during the calendar yearAugust $1^{\text {st }}$ from December 31, in 2014.

\section{Units of Analysis}

The unit of analysis for this study consisted of News, News stories, editorials, articles, Photos published in the four selected dailies.

\section{News Frames and Operational definitions}

Keeping in view of research hypothesis and research question of the study 5 main frames have been identified.

1). Diplomatic Frame: All reports, analysis and editorials introduced events froma diplomatic point of view and tracked current events within the overall progression of diplomatic plans.

2).Military Frame: This frame mention of success and failures of the military approach, military goals, military death tolls, civilian casualties, policy and political developments in relation to the military approach.

3).Violence Frame: This frame mention of violent activities by ISIS for instance kidnapping of innocent people and throat cutting, destructions of public and government property.

4).Human ImpactFrame: This frame focused on the descriptions of individual and groups affected by ISIS.

5). Mixed Frame: Which are not fit in above news frames researcher coded in this mixed frame.

\section{Procedures of measurement}

The unit of analysis coded into various news frames, were measured both in terms of their frequencies and space.

\section{Directional Analysis}

The purpose of using the directional analysis is to find out how the newspapers accorded treatment to terrorist attacks. The subject categories analysed to find out the treatment given by the four newspapers on a 3 point scale: favourable, unfavourable and neutral. 


\section{Statistical techniques used}

For analysing the data the following statistical measures have been used: simple percentage, co- efficient of imbalance and chi- square.

\section{Results and Discussion}

Table-1Total number of Units of Analysis in selected Dailies

\begin{tabular}{|c|c|c|c|c|}
\hline Unit Analysis & Frequency & $\%$ & Space & $\%$ \\
\hline News & 292 & 47.6 & 49797 & 74.6 \\
\hline Byline News & 48 & 7.8 & 8304 & 12.4 \\
\hline Photo & 250 & 40.8 & - & - \\
\hline Editorial & 5 & 0.8 & 1063 & 1.6 \\
\hline Article & 9 & 1.5 & 4157 & 6.3 \\
\hline Comments & 9 & 1.5 & 3416 & 5.1 \\
\hline$N$ & 613 & 100.0 & 66737 & 100.0 \\
\hline
\end{tabular}

Table 1 shows that total news units 292, Byline News 48,Photos 250, Editorials 5, Articles 9, Comments 9, came up for analysis in these four newspapers.

Table-2 Distribution of Units of Analysis by Frequencies in the Sample Dailies

\begin{tabular}{|c|c|c|c|c|c|c|c|c|}
\hline \multirow{2}{*}{ Unit analysis } & \multicolumn{2}{l|}{ The Hindu } & \multicolumn{2}{l|}{ The Times of India } & \multicolumn{2}{l|}{ Andhrajyothi } & \multicolumn{2}{l|}{ Prajasakthi } \\
\cline { 2 - 10 } & fr & Sp & fr & Sp & fr & sp & fr & sp \\
\hline News & 66 & 9694 & 124 & 27665 & 55 & 6662 & 47 & 5776 \\
\hline Byline News & 48 & 8304 & - & - & - & - & - & - \\
\hline Photo & 84 & - & 115 & - & 28 & - & 23 & - \\
\hline Editorial & - & - & 3 & 550 & 2 & 513 & - & - \\
\hline Article & 3 & 1650 & 2 & 842 & - & - & 4 & 1665 \\
\hline Comments & 9 & 3416 & - & - & - & - & - & - \\
\hline$N$ & 210 & 23064 & 244 & 29057 & 85 & 7175 & 74 & 7441 \\
\hline
\end{tabular}

Table 2shows that total news items published on ISIS and newspapers in selected dailies are 613 with $66737 \mathrm{col}$. cms space. In selected dailiesThe Hinducover 210 items with $23064 \mathrm{cms}$ space, followed by The Times of India 244 with $29057 \mathrm{cms}$ space, Andhrajyothi85 with $7175 \mathrm{cms}$ space andPrajasakthi74 with $7441 \mathrm{col}$. cms space.

Table-3Distribution of Newspaper location Analysis of the ISIS News Items in Selected Dailies

\begin{tabular}{|c|c|c|c|c|c|c|}
\hline \multirow{2}{*}{$\begin{array}{c}\text { Name of the } \\
\text { Newspaper }\end{array}$} & \multicolumn{2}{|c|}{ Front Page } & \multicolumn{2}{c|}{ Inside Page } & \multicolumn{2}{c|}{ Edit Page } \\
\cline { 2 - 7 } & $\mathrm{fr}$ & $\mathrm{sp}$ & $\mathrm{Fr}$ & $\mathrm{Sp}$ & $\mathrm{fr}$ & $\mathrm{sp}$ \\
\hline The Hindu & 4 & 320 & 185 & 17678 & 21 & 5066 \\
\hline $\begin{array}{c}\text { The Times of } \\
\text { India }\end{array}$ & 14 & 984 & 221 & 2668 & 9 & 1392 \\
\hline Andhrajyothi & 2 & 592 & 81 & 6070 & 2 & 513 \\
\hline Prajasakthi & - & - & 68 & 5776 & 6 & 1665 \\
\hline $\mathrm{N}$ & 20 & 1896 & 555 & 32192 & 38 & 8636 \\
\hline
\end{tabular}

Table 3 reveals that location of content on ISIS and newspapers in selected dailies. Majority of news items 555 with $32192 \mathrm{col}$. cms space covered in inside pages, In front page coverage only 20 items with $1896 \mathrm{col}$. cms 
space and Edit page covered 38 items with $8636 \mathrm{col}$. cms space. In all selected dailies The Times of India gave more priority to publish inside pages 221 with2668 compare to other selected dailies. In front page also The Times of India publishes 14 items 984 compare to other selected dailies. In Edit pages The Hindu gave priority to publish 21 items $5066 \mathrm{col}$. cms space other than selected dailies.

Table 4 shows that coverage of the News frames by the selected dailies. 'Diplomatic Frame' covered by better in The Hindu 70 with $8527 \mathrm{col}$. cms space, The Times of India gave priority to publish 'Military Frame'sub theme covered better 94 with $10843 \mathrm{col}$. cms space compare to other selected dailies, 'Violence Frame'covered in better by The Times of India 98 with 11152 spaces'Human Impact Frame' covered better in also The Times of India 14 with 1392 space.

Table 5 explains that Direction of Treatment ISIS and new papers in selected dailies, majority of news items 504 with 53257col. cms space covered in Favourable coverage to ISIS, In Unfavourable coverage only 79 items with $10293 \mathrm{col}$. cms space and Neutral coverage 30 items with $3187 \mathrm{col} . \mathrm{cms}$ space.

In all selected dailies The Times of Indiagave more priority to publishFavourable coverage to ISIS228 with 27533 compare to other selected dailies. In Unfavourable coverage The Hindu publishes 30 items 4660 compare to other selected dailies. In Neutral coverage The Hindu and Andrajyothi gave priority to publish each 9 items.

Table-4 DistributionPercentages of Frequencies and Space by News Frames in the Sample Dailies

\begin{tabular}{|c|c|c|c|c|c|c|c|c|}
\hline \multirow[t]{2}{*}{ Framing Analysis } & \multicolumn{2}{|c|}{ The Hindu } & \multicolumn{2}{|c|}{ The Times of India } & \multicolumn{2}{|c|}{ Andhrajyothi } & \multicolumn{2}{|c|}{ Prajasakthi } \\
\hline & $\begin{array}{c}\mathrm{fr} \\
(\%)\end{array}$ & $\begin{array}{l}\mathrm{Sp} \\
(\%)\end{array}$ & $\begin{array}{l}\mathrm{fr} \\
(\%)\end{array}$ & $\begin{array}{l}\mathrm{sp} \\
(\%)\end{array}$ & $\begin{array}{c}\mathrm{fr} \\
(\%)\end{array}$ & $\begin{array}{l}\mathrm{sp} \\
(\%)\end{array}$ & $\begin{array}{c}\text { fr } \\
(\%)\end{array}$ & $\begin{array}{l}\mathrm{sp} \\
(\%)\end{array}$ \\
\hline Diplomatic Frame & $\begin{array}{c}70 \\
(33.3) \\
\end{array}$ & $\begin{array}{c}8527 \\
(37.0) \\
\end{array}$ & $\begin{array}{c}30 \\
(12.3) \\
\end{array}$ & $\begin{array}{c}5106 \\
(17.6)\end{array}$ & $\begin{array}{c}18 \\
(21.2)\end{array}$ & $\begin{array}{c}2018 \\
(28.1)\end{array}$ & $\begin{array}{c}35 \\
(47.3)\end{array}$ & $\begin{array}{c}4242 \\
(57.0)\end{array}$ \\
\hline Military Frame & $\begin{array}{c}64 \\
(30.5)\end{array}$ & $\begin{array}{c}6556 \\
(28.4)\end{array}$ & $\begin{array}{c}94 \\
(38.5)\end{array}$ & $\begin{array}{l}10843 \\
(37.3)\end{array}$ & $\begin{array}{c}17 \\
(20.0)\end{array}$ & $\begin{array}{c}1227 \\
(17.1)\end{array}$ & $\begin{array}{c}17 \\
(23.0)\end{array}$ & $\begin{array}{c}1325 \\
(17.8)\end{array}$ \\
\hline Violence Frame & $\begin{array}{c}64 \\
(30.5)\end{array}$ & $\begin{array}{c}6771 \\
(29.3)\end{array}$ & $\begin{array}{c}98 \\
(40.2)\end{array}$ & $\begin{array}{l}11152 \\
(38.4)\end{array}$ & $\begin{array}{c}29 \\
(34.1)\end{array}$ & $\begin{array}{c}2066 \\
(28.8)\end{array}$ & $\begin{array}{c}20 \\
(27.0)\end{array}$ & $\begin{array}{c}1677 \\
(22.5)\end{array}$ \\
\hline Human Impact Frame & $\begin{array}{c}4 \\
(1.9)\end{array}$ & $\begin{array}{c}366 \\
(1.6) \\
\end{array}$ & $\begin{array}{c}14 \\
(5.7)\end{array}$ & $\begin{array}{l}1392 \\
(4.8) \\
\end{array}$ & $\begin{array}{c}13 \\
(15.3)\end{array}$ & $\begin{array}{c}1160 \\
(16.2)\end{array}$ & $\begin{array}{c}2 \\
(2.7) \\
\end{array}$ & $\begin{array}{c}197 \\
(2.7) \\
\end{array}$ \\
\hline Mixed Frame & $\begin{array}{c}8 \\
(3.8)\end{array}$ & $\begin{array}{c}844 \\
(3.7)\end{array}$ & $\begin{array}{c}8 \\
(3.3)\end{array}$ & $\begin{array}{c}564 \\
(1.9)\end{array}$ & $\begin{array}{c}8 \\
(9.4)\end{array}$ & $\begin{array}{c}704 \\
(9.8)\end{array}$ & - & - \\
\hline $\mathrm{N}$ & $\begin{array}{c}210 \\
(100.0)\end{array}$ & $\begin{array}{c}23064 \\
(100.0) \\
\end{array}$ & $\begin{array}{c}244 \\
(100.0) \\
\end{array}$ & $\begin{array}{c}29057 \\
(100.0) \\
\end{array}$ & $\begin{array}{c}85 \\
(100.0) \\
\end{array}$ & $\begin{array}{c}7175 \\
(100.0) \\
\end{array}$ & $\begin{array}{c}74 \\
(100.0) \\
\end{array}$ & $\begin{array}{c}7441 \\
(100.0) \\
\end{array}$ \\
\hline
\end{tabular}

Table-5 Directional Analysis of Coverage of the ISIS News Items in Selected Dailies

\begin{tabular}{|c|c|c|c|c|c|c|}
\hline \multirow{2}{*}{$\begin{array}{c}\text { Name of the } \\
\text { News Paper }\end{array}$} & \multicolumn{2}{|c|}{ Favourable } & \multicolumn{2}{c|}{ Unfavourable } & \multicolumn{2}{c|}{ Neutral } \\
\cline { 2 - 7 } & $\mathrm{fr}$ & $\mathrm{Sp}$ & $\mathrm{Fr}$ & $\mathrm{Sp}$ & $\mathrm{fr}$ & $\mathrm{Sp}$ \\
\hline The Hindu & 171 & 17020 & 30 & 4660 & 9 & 1384 \\
\hline $\begin{array}{c}\text { The Times of } \\
\text { India }\end{array}$ & 228 & 27533 & 8 & 960 & 8 & 564 \\
\hline Andhrajyothi & 59 & 5037 & 17 & 1332 & 9 & 806 \\
\hline Prajasakthi & 46 & 3667 & 24 & 3341 & 4 & 433 \\
\hline $\mathrm{N}$ & 504 & 53257 & 79 & 10293 & 30 & 3187 \\
\hline
\end{tabular}

Table 6. Direction of treatment and coefficient of imbalance of four selected newspapers

\begin{tabular}{|l|c|c|c|c|c|}
\hline \multirow{2}{*}{ Dailies } & \multirow{2}{*}{$\mathrm{N}$} & \multicolumn{3}{|c|}{ Direction of Covering } & \multirow{2}{*}{$\begin{array}{c}\text { Coefficient of } \\
\text { Imbalance }\end{array}$} \\
\cline { 3 - 5 } & & $\mathrm{F}$ & $\mathrm{UF}$ & $\mathrm{Ne}$ & 0.104700 \\
\hline The Hindu & 210 & 171 & 30 & 9 & 0.031600 \\
\hline The Times of India & 244 & 228 & 8 & 8 & 0.123614 \\
\hline Andrajyothi & 85 & 59 & 17 & 9 & 0.107755 \\
\hline Prajasakthi & 74 & 46 & 24 & 4 & \\
\hline \multicolumn{1}{|c|}{ Total } & 613 & 504 & 79 & 30 & \\
\hline
\end{tabular}

$\mathrm{n}=$ number of news items; $\mathrm{F}=$ favourable; $\mathrm{UF}=$ unfavourable; $\mathrm{Nu}=$ neutral

$$
\chi^{2}=51.769, d f=7, P=0.0001
$$


The coefficient of imbalance was used to find out the degree of treatment given to different subject categories by the sample dailies. For this purpose, a three point scale namely Favourable, Unfavourable and Neutral was adopted to assess the direction of the treatment of the themes. Among the four sample dailies, three were published more number of favourable news items ie., The Hindu (171), The Times of India (228)and Andrajyothi (59). But Prajasakthi published very less number of favourable news items (74).Among the four selected dailies, The Hindu put more emphasis on the negative coverage of ISIS violent activity related news items (0.104700), throughout the study period. Were as the two Telugu dailies Andrajyothi gave critical treatment to the ISIS related news by emphasizing on negative responses $(0.123614)$.

\section{Key Findings:}

Four selected dailies gave much priority to publish news and photos than editorial and other news units. The English newspaper The Times of India published more news items than The Hindu; in the same manner Telugu newspaper Andhra Jyothi gave importance than Prajasakhti.

In location coverage four selected newspapers were preferred to publish ISIS news in inside pages that is international news section, rarely published in first page, The Hindu published more editorial content than other selected dailies.

The Times of Indiagave much priority to violence frames and military frames than diplomatic frame but The Hindu gave much priority to diplomatic frame.

Violent and military frames are equally treated by The Hindu newspaper.Lot of percentage variation between violent and diplomatic frames in two English dailies.

In Telugu news daily AndhraJyothi gave much priority to violent frame but other Telugu newspaper Prajasakthi gave more coverage to diplomatic frame.

The English newspaper The Times of Indiapublished more favourable news to ISIS than The Hindu, In Telugu dailies AndhraJyothi gave much favourable to ISIS than Prajasakti.

The Hindu published more unfavourable news to ISIS than The Times of India; In Telugu newspapers Prajasakti published more unfavourable news than Andhra jyothi.

\section{Conclusion}

In this paper, the researchers have looked ISISat the global level, the problem of ISIS terrorism and its impact of mass media on youth.Former Prime- Minister of Great Britain Margaret Thatcher's valuable saying "Oxygen providers without which terrorists would not survive (Holmes, D., 2007). With the extensive coverage of terrorist activities in Mass Media, the people are subjected to the continuous bombardment of devastating activities under the canopy of "News Framing", thereby getting indirectly influenced.Had media would not give due importance in the coverage of terrorist activities, the public would not have been influenced much. However, they are subjected to the "News Framing" continuously and are getting affected.

To affirm this fact, recently a 22 year old boy who had been attracted to ISIS and started recruiting youngsters to ISIS. This Incident shocked the public and police; this asserts the ISIS impact on Indian youth.Theyare attracted to the ISIS activities because of the continuous exposition by media and are easily falling prey to the ISIS unknowingly. Being the Fourth Estate, Media should be self-aware of the news it is publishing and should have self-imposed guidelines in coverage of terrorism and related events for the betterment of the society. Media should beconscious enough to stop exposing the derogatory news of terrorist related activities and in fact should publish articles, columns, editorials on terrorism and its negative impact on public life and development.

To sum up, Media should consciously aware while publishing news related to terrorist activities and make sure to ignite the psyches of public regarding the predicaments of terrorism. 


\section{References}

[1] Aday, S., Livingston, S., \& Hebert, M. (2005). Embedding the truth a cross-cultural Analysis. Analysis of Frames Employed in Terrorism Coverage in U.S. and U.K Newspapers and our understanding of the social world / edited by Stephen D. Reese, Oscar H. Associates.

[2] Ahsan (2015). ISIS and Media: International Relations Insights \& Analysis All rights reserved.

[3] Barnett, B., \& Reynolds, A. (2009). Terrorism and the Press: An Uneasy Relationship. New York: Peter Lang Publishing, Inc.

[4] De Vreese, C. H. (2005). News framing: Theory and typology. Information design journal+ Defence of the Republic of Macedonia.document design, 13(1), 51-62.

[5] Dimitrova, D. V., Kaid, L. L., Williams, A. P., \& Trammell, K. D. (2005). War on the Web: The government, and the public / edited by Pippa Norris, Montague Kern, and Marion Just. New York: New York : Routledge.

[6] Fahmy, S., \& Al-Emad, M. (2012). Did Al-Jazeera's Online Coverage Change Over Time? Comparing the Reporting of the Iraq war in 2004 versus 2007. Global Media Journal, Vol. 2, Nos 1-2.

[7] Gandy, Jr., August E. Grant. Mahwah, N.J . Mahwah, N.J .: Lawrence Erlbaum Journal of Press/Politics, 10(1), 321.

[8] Gans, H. J. (1979). Deciding what's news: A study of CBS evening news, NBC nightly news, Newsweek, and Time: Northwestern University Press.

[9] Goffman, E. (1974). Frame analysis: An essay on the organization of experience: Harvard University Press.

[10] Holmes. D. 2007. Plenty of Oxygine: Terrorism. News media and the politics of the security State world communication Association conference. Date views 11.10.2013

[11] Iyengar, S. (1994).Is anyone responsible?: How television frames political issues. University of Chicago Press.

[12] Jasperson, A., \& Kikhia, M. (2003). CNN and Al-Jazeera's media coverage of America's war in Afghanistan. Framing terrorism: The news media, the government, and the public, 113-132.

[13] McQuail, D. (2009). McQuail's mass communication theory: Sage publications.

[14] Nacos, B. (2002). Mass-mediated Terrorism: The Central Role of the Media in Terrorism and Counterterrorism. New York: Rowman and Littlefield Publishers, Inc.

[15] Neuman, W. R., Just, M. R., \& Crigler, A. N. (1992). Common knowledge: News and the Construction of Political Meaning. Chicago: University of Chicago Press.

[16] Norris, P., Kern, M., \& Just, M. R. (2003). Framing terrorism: the news media, the government, and the public / edited by Pippa Norris, Montague Kern, and Marion Just.New York: New York :Routledge.

[17] Papacharissi, Z., \& Oliveira, M. d. F. (2008). News Frames Terrorism: A Comparative Press/Politics, 10(1), 22-44. doi:10.1177/1081180X0527559.

[18] Riffe,D., Lacy,S., Filo,F., 9(2005)Analyzing Media Messages: Using Quantitative Content Analysis in Approach. New Jersey: Lawrence Erlbaum Associtations, Jmc

[19] (Rohan Gunaratna 2016) GLOBAL TERRORISM IN 2016: Revista UNISCI / UNISCI .Journal, No 40 (Enero / January 2016)

[20] Schaefer, T. M. (2003). Framing the US embassy bombings and September 11 attacks In African and US newspapers.Framing terrorism: The news media, the government and the public, 93-112.

[21] Semetko, H. A., \& Valkenburg, P. M. (2000). Framing European politics: A content analysis of press and television news. Journal of communication, 50(2), 93-109. 